\title{
An Analysis of the Behaviour of Select Indian Mutual Funds during the Financial Crisis of the Year 2008
}

\author{
Soheli Ghosh ${ }^{1}$ and Dr. Dipti Kumar Chakravorty ${ }^{2}$ \\ 1. Research Scholar (Ph.D Programme), Department of Commerce, Calcutta University, India. \\ 2. Professor, Department of Commerce, Calcutta University. India.
}

\begin{abstract}
The essence of a Mutual Fund is the portfolio of investment, which diversifies and reduces the risk by spreading out the investor's money across available different types of investments. Through our study we have analyzed how few selected Mutual Fund Schemes behave during the period of December 2008 to December 2012 , i.e. during the global meltdown and the period thereafter. We have analyzed the coefficient of variation of the return generated by the Sensex, Company Scrips and the Mutual Fund Schemes to determine a more stable series, the Managerial Efficiency of the selected Mutual Fund Schemes in stock selection, the Sharpe ratio and the pattern of return generated by the selected Mutual Fund Schemes before 2008 and after 2008. We found that the variability in the return of the Mutual Fund Schemes are between moderate to high and thus these Mutual Fund Schemes may not be as stable as they seem to be. The investors should weigh their options carefully before deciding to invest in a Mutual Fund Scheme.
\end{abstract}

Key Words: Equity Diversified Mutual Fund Schemes, Sensex Return, Variability in return.

\section{Background Of The Study}

Indian Mutual Funds are playing a very crucial developmental role in allocating resources in the emerging market economy by mobilizing savings by issuing units and channelling funds in the capital market into productive investment. According to the Association of Indian Mutual Fund Industry, "A Mutual Fund is a trust that pools the savings of a number of investors who share a common financial goal. The money thus collected is then invested in capital market instruments such as shares, debentures and other securities. The income earned through these investments and the capital appreciation realized is shared by the unit holders in the proportion to the number of units owned by them. Thus a mutual fund is the most suitable investment for the common man as it offers an opportunity to invest in a diversified professionally managed basket of securities at a relatively low cost." The first Mutual Fund scheme was launched in India by UTI in 1964 and since then the industry has seen a lot of growth in terms of new Mutual Fund schemes and their returns. In March 1965 the AUM was INR 25 crore. As on $31^{\text {st }}$ March 2013 the total AUM was INR 702493.8 crore. As on $31^{\text {st }}$ December 2012 there were 41 Fund Houses.

\section{Literature Review}

Treynor (1965) [1] developed the Treynor Ratio that measures returns earned in excess of that which could have been earned on a risk less investment per each unit of market risk. The most prominent study by Sharpe (1966) [2] developed a composite measure of return and risks the Sharpe Ratio. He evaluated 34 openend mutual funds for the period 1944-63. The results depicted that good performance was associated with low expense ratio and not with the size. Jensen (1967) [3] derived a risk-adjusted measure of portfolio performance (Jensen's alpha) that estimates how much a manager's forecasting ability contributes to fund's returns. Fama (1972) [4] developed methods to distinguish observed return due to the ability to pick up the best securities at a given level of risk from that of predictions of price movements in the market. Shashikant $U$ (1993) [5] pointed out that money market mutual funds with low-risk and low return offered conservative investors a reliable investment avenue for short-term investment. Narasimhan and Vijayalakshmi (2001) [6] analysed the top holding of 76 mutual fund schemes from January 1998 to March 1999. The study showed that, 62 stocks were held in portfolio of several schemes, of which only 26 companies provided positive gains. The top holdings represented more than 90 percent of the total corpus in the case of 11 funds. The top holdings showed higher risk levels compared to the return. The correlation between portfolio stocks and diversification benefits was significant at one percent level for 30 pairs and at five percent level for 53 pairs. Badrinath (2008) [7] carried out a study on contra funds with a special emphasis on SBI Contra Fund and found that the performance of SBI Contra Fund was superior to that of the general equity diversified market. Swaminathan (2011) [8] analysed the performance of 130 open ended mutual fund schemes from April 2003 to March 2008. The results showed that the private sector schemes performed better than their public counterparts and growth schemes were the best schemes. Shitole and Thyagarajan (2012) [9] evaluated the performance of three AMCs, namely, ICICI 
Prudential AMC, HDFC AMC and Franklin Templeton AMC and opined that most funds were able to provide market related returns and many schemes outperformed their respective benchmark indices.

\section{Objectives Of The Study}

Through our study we have analysed how few selected Mutual Fund Schemes behave during the period of December 2008 to December 2012 in comparison to few chosen company scrips. It is generally believed that mutual funds are less volatile as compared to individual company scrips \& stocks \& that investing in mutual funds would yield more return at the given risk when compared to company stocks. Before 2008 the Indian Financial Market was flourishing at an accelerated pace and the adverse effect of the Global economic crunch was felt only towards the latter half of 2008. Thus we have chosen a time period of December 2008 to December 2012 to study these mutual funds during the international financial crisis to understand their behaviour in volatile markets. The objectives of this study are as follows:

1. To study the the coefficient of variation between few chosen company scrips with that of the Sensex return and mutual fund return.

2. To understand the Managerial Efficiency of the selected Mutual Fund Schemes in stock selection.

3. To understand the fluctuation in the Sharpe Ratio of these Mutual Fund Schemes.

4. To understand the pattern of return generated by the selected Mutual Fund Schemes before 2008 and after 2008.

\section{Data Source And Research Methodology}

Data Source: Data have been obtained from the official websites of the different mutual fund houses, websites of Bombay Stock Exchange (BSE) and National Stock Exchange (NSE), AMFI, SEBI (website as well as SEBI Handbook of Statistics on Indian Securities Market), RBI (website as well as RBI Handbook of Statistics on Indian Economy), valueresearchonline (website as well as Mutual Fund Year Book 2008 to 2013, Mutual Fund Insight Magazine January 2008 to January 2013, Wealth Insight Magazine January 2008 to January 2013), Personal Finance Investment Workbook, various reports and articles published in financial dailies, finance based magazines and periodicals.

Sample: First a sample of top 50 ranked Equity Diversified Mutual Funds of the year 2008 (starting point of the study) was taken based on their return generated. This ranking was done by Valueresearch an authentic and popular Mutual Fund Research organization. From this, 12 schemes were selected at random. They are DSPBR Equity, DSPBR Top 100 Equity Reg G, DWS Investment Opportunities Reg ( 3 Foreign Sector Schemes ), HDFC Growth, ICICI Pru Infrastructure, Kotak Opportunities, Reliance Growth, Reliance Regular Savings Equity G, Sundaram Select Midcap Reg G, Tata Equity PE G ( 7 Private Sector Schemes ), SBI (Magnum) Contra G, UTI Dividend Yield ( 2 Public Sector Schemes ). The 10 Companies were chosen based on the fact that most of the Mutual Fund Schemes being studied here have invested in these company scrips in their portfolio. The companies chosen are Grasim Industries, HDFC Bank, ICICI Bank, Indusind Bank, Infosys, Larsen and Toubro, Reliance Industries, SBI, United Spirits, and Zee Entertainment Enterprise. The reason for choosing these companies was that as most of the 12 Mutual Fund Schemes have stocks of these companies in their portfolio, it would make sense to observe the behaviour of these 12 Mutual Fund Schemes individually and then compare it with the behaviour of these 10 Company Scrips in isolation.

Methodology: In the first part of the study we have analysed the coefficient of variation of the return generated by the Sensex, Company Scrips and the Mutual Fund Schemes. The series with a comparatively less coefficient of variation would be considered more stable as compared to the others. Through the analysis we are trying to see whether it is more beneficial for an investor to invest in these scrips directly or through the mutual fund schemes. Charts have been used to compare the return generated by these funds and Sensex. Here every quarter of the study period has been considered i.e. starting from the Quarter January 08 to March 08 and ending with the Quarter October 12 to December 12. In the second part we have studied the efficiency of the manager in stock selection and diversification of the funds by testing the Alpha, Beta, R Square and Sharpe Ratio of the funds over a period of January 2010 to December 2012. Here the risk free return rate has been taken as $8 \%$ which is the approximate Average rate of Public Provident Fund prevalent rates between 2005 and 2012. This has been considered as the study period lies within this time frame. Finally we have studied the pattern of the quarterly return generated by the 12 Mutual Fund Schemes before January 2008 and after January 2008 each time period being taken as a set. We have taken one set staring from January 2008 to December 2012 which is essentially after the Global Meltdown. Another set has been taken from October 2005 to December 2007 considering that the major effect of the Global Meltdown on the Indian Financial Markets started during December 2007. We had to start from the October Quarter in 2005 as the Fund ICICI Pru Infrastructure was launched in August 2005. In this way two sets of independent sample were considered. To analyze the data we have used Independent Sample' $t$ ' test of 'Equality of Means' ( 2 tailed tests and 5\% level of significance). Here we have taken two types of return [Percentage Return and the Log form of the return which is Log (Return of 
period' $t$ ' / Return of period ' $\left.t-1^{\prime}\right)$ ]. If $p$ value is less than 0.05 we reject the Null Hypothesis and claim that the sample means are not same.

\section{Analysis And Inferences}

5.1 Analysis Of The Coefficient Of Variation Of Individual Mutual Fund Schemes Return With Company Scrips Return And Sensex:

We have analysed the coefficient of variation between the percentage return generated by the 12 Mutual Fund Schemes and the 10 Company Scrips chosen. The coefficient of variation was observed to be comparatively less for the company scrips than that of the Mutual Fund Schemes. Excepting HDFC Bank (2918.23), Larsen and Toubro (1425.03), Grasim Industries (1286.77) and Zee Entertainment Enterprise (3123.97), the other companies had low coefficient of variation. It is also observed that the Mutual Fund Schemes had very high variability especially that of DSPBR Equity (7336.9), DWS Investment Opportunity (8877.95), ICICI Pru Infrastructure (3073.72), and Kotak Opportunities (2429.11). The Coefficient of Variation of Sensex was 2466.84. Thus it can be said that the fluctuation in the return of these companies were less as compared to the Mutual Fund Schemes in general. This is because the Mutual Fund Schemes invested in other companies also to diversify their portfolio and thus their variation increased even further rather than actually minimizing the variation. Thus though it is believed that investing in a Mutual Fund Scheme may generate higher returns than investing in Companies directly, it may not be true always. Also the coefficient of variation in the Mutual Fund Schemes is comparatively higher than that of the chosen company scrips making it more volatile. However the diversification of the Mutual Fund Schemes does reduce the risk in some cases (Table 1).

\subsection{Study Of The Fund Managers Efficiency In Selecting Stocks For The Portfolio And Diversification Of The Funds.}

A positive alpha value signifies superior and positive stock selection ability by the fund manager and a negative alpha value suggests poor stock selection by the fund manager. Beta measures the systematic risk associated with the fund which exists because of the variability in the market return. $R$ Square $\left(R^{2}\right)$, the coefficient of determination measures the extent of diversification which is used to reduce the degree of unique/systematic risk. The value ranges between 0 and 1 . R Square value of 1 implies a completely diversified portfolio having zero unique risk. R Square and Beta help in understanding the relationship of the fund with its benchmark and the extent of market risk. It was observed that though in all the funds the Average RSQ was high indicating diversification to minimize Average Beta, the Average Alpha was negative in some funds. This indicated that the fund managers were not so efficient in selecting stocks for all the funds (Table 2).

\subsection{Study Of The Sharpe Ratio Of The Individual Mutual Funds}

A positive Sharpe ratio denotes that the returns generated by the chosen funds are in excess of the risk free return rate. This analysis checks whether the Mutual Fund Scheme is generating a higher return than the Risk Free Return prevalent in the market during the period of study, thereby understanding its performance in a new perspective. It is observed that overall in most of the funds (excepting SBI ((Magnum)) Contra, ICICI Pru Infrastructure, Kotak Opportunity G and DWS Investment Opportunity Reg G) the Average Sharpe Ratio was positive throughout the study period, indicating that their return was more than the Risk Free Return. Even in the 4 funds where negative Sharpe Ratio was seen in one or two time points out of the entire time period and the remaining part of the study period the ratio was positive. This lead to the overall positive average Sharpe Ratio for all the funds (Table 3).

\subsection{Study Of The Return Generated By The Individual Mutual Fund Schemes Before And After January} 2008.

We have studied the pattern of the quarterly return generated by the 12 Mutual Fund Schemes before and after January 2008 each time period being taken as a set.

Null Hypothesis HO: The mean of the return generated by the Mutual Fund Schemes are same across the two independent sample time periods. Thus there is no significant Variation in the two sample means.

Alternate Hypothesis H1: The mean of the return generated by the Mutual Fund Schemes are not same across the two independent sample time periods. Thus there is significant Variation in the two sample means.

5.4.1) In the first part we had analyzed the percentage return. 10 out of the 12 Mutual Fund Schemes have a $p$ value greater than 0.05 . Thus we accept the Null Hypothesis and claim that there is no statistically significant variation in the means of the two independent samples of the two time periods chosen. Thus for these Mutual Fund Schemes the annualized return before January 2008 is same as annualized return after January 2008. Only in case of DWS Investment Opportunities Reg G and ICICI Pru Infrastructure the $p$ value was less than 0.05 
thereby rejecting the Null Hypothesis. Thus in this case there is a statically significant variation in the means of the two samples of time period chosen (Table 4).

5.4.2) In the second part we had analyzed the LOG return. 9 out of the 12 Mutual Fund Schemes have a p value greater than 0.05 . Thus we accept the Null Hypothesis and claim that there is no statistically significant variation in the means of the two independent samples of the two time periods chosen. Thus for these Mutual Fund Schemes the annualized return before January 2008 is same as annualized return after January 2008. Only in case of DWS Investment Opportunities Reg G, ICICI Pru Infrastructure and Kotak Opportunities G the p value was less than 0.05 thereby rejecting the Null Hypothesis (Table 5).

\section{Tables}

Table 1: Coefficient of Variation between Mutual Fund Returns, Return generated by the Companies and Sensex Return.

\begin{tabular}{|l|l|}
\hline & Coefficient of Variation \\
\hline Grasim & 1286.77 \\
\hline HDFC Bank & 2918.23 \\
\hline ICICI Bank & 1128.95 \\
\hline Indusind Bank & 360.20 \\
\hline Infosys & 669.72 \\
\hline Larsen and Toubro & 1425.03 \\
\hline Reliance Industries & 442.02 \\
\hline SBI & 1002.44 \\
\hline United Spirits & 925.62 \\
\hline Zee Entertainment Ent & 3123.97 \\
\hline DSPBR Eq & 7336.90 \\
\hline DSPBR Top 100 Eq Reg G & 910.91 \\
\hline DWS Investment Opportunity & 8877.95 \\
\hline HDFC Growth & 943.48 \\
\hline ICICI Pru Infra & 3073.72 \\
\hline Kotak Opportunity & 2429.11 \\
\hline Reliance Growth & 1299.52 \\
\hline Reliance Regular Savings Eq & 1072.24 \\
\hline SBI (Magnum) Contra & 2309.68 \\
\hline Sundaram Select Midcap Reg G & 591.85 \\
\hline Tata Eq PE & 1221.32 \\
\hline UTI Div Yield & 680.26 \\
\hline Sensex & 2466.84 \\
\hline & \\
\hline
\end{tabular}

Table 2: Average R Square, Alpha and Beta of the Mutual Fund Schemes.

\begin{tabular}{|l|c|c|c|}
\hline & R Square & Alpha & Beta \\
\hline DSPBR Equity D & 0.92 & 5.08 & 0.89 \\
\hline DSPBR Top 100 Equity Reg G & 0.96 & 3.92 & 0.82 \\
\hline DWS Investment Oppor Reg & 0.93 & 0.10 & 0.9 \\
\hline HDFC Growth & 0.94 & 5.14 & 0.88 \\
\hline ICICI Pru Infra & 0.94 & -2.71 & 0.93 \\
\hline Kotak Oppor G & 0.94 & 1.29 & 0.97 \\
\hline SBI Magnum Contra & 0.96 & -0.35 & 0.98 \\
\hline Reliance Growth & 0.91 & 3.56 & 0.99 \\
\hline Reliance Regular Savings Eq & 0.89 & 5.11 & 1.04 \\
\hline Sundaram Select Midcap Reg G & 0.82 & 6.16 & 1.14 \\
\hline Tata Equity PE & 0.92 & 5.33 & 0.97 \\
\hline UTI Dividend Yld & 0.93 & 7.77 & 0.78 \\
\hline
\end{tabular}


Table 3: Average Sharpe ratio of the Mutual Fund Schemes.

\begin{tabular}{|l|r|}
\hline & Sharpe Ratio \\
\hline DSPBR Equity D & 0.45 \\
\hline DSPBR Top 100 Equity Reg G & 0.45 \\
\hline DWS Investment Oppor Reg & 0.27 \\
\hline HDFC Growth & 0.58 \\
\hline ICICI Pru Infra & 0.24 \\
\hline Kotak Oppor G & 0.33 \\
\hline SBI Magnum Contra & 0.28 \\
\hline Reliance Growth & 0.38 \\
\hline Reliance Regular Savings Eq & 0.44 \\
\hline Sundaram Select Midcap Reg G & 0.4 \\
\hline Tata Equity PE & 0.43 \\
\hline UTI Dividend Yld & 0.56 \\
\hline
\end{tabular}

Table 4: Interaction between Percentage Return of the Mutual Funds before January 2008 and from January 2008 (using equality of means' $t$ ' test).

\begin{tabular}{|l|l|l|l|l|}
\hline & Mean \pm SD (PRE) & Mean \pm SD (POST) & P Value & SIGNIFICANCE \\
\hline DSPBR Eq & $8.75 \pm 17.38$ & $-0.23 \pm 16.87$ & 0.200 & Not Significant \\
\hline DSPBR Top 100 Eq Reg G & $12.08 \pm 11.39$ & $1.52 \pm 13.85$ & 0.056 & Not Significant \\
\hline DWS Investment Oppor & $13.66 \pm 15.67$ & $-0.17 \pm 14.83$ & 0.030 & Significant \\
\hline HDFC Growth & $11.7 \pm 13.29$ & $1.68 \pm 15.86$ & 0.111 & Not Significant \\
\hline ICICI Pru Infra & $15.11 \pm 15.69$ & $-0.46 \pm 14.17$ & 0.013 & Significant \\
\hline Kotak Oppor & $13.72 \pm 15.14$ & $0.68 \pm 16.41$ & 0.053 & Not Significant \\
\hline Reliance Growth & $12.25 \pm 13.59$ & $1.37 \pm 17.76$ & 0.115 & Not Significant \\
\hline Reliance Regular Savings Eq & $14.04 \pm 18.65$ & $1.69 \pm 18.14$ & 0.104 & Not Significant \\
\hline SBI (Magnum) Contra & $13.11 \pm 12.68$ & $0.7 \pm 16.05$ & 0.051 & Not Significant \\
\hline Sundaram Select Midcap Reg G & $11.18 \pm 13.9$ & $3.67 \pm 21.73$ & 0.351 & Not Significant \\
\hline Tata Eq PE & $12.24 \pm 12.97$ & $1.36 \pm 16.65$ & 0.095 & Not Significant \\
\hline UTI Div Yld & $9.96 \pm 13.03$ & $1.94 \pm 13.2$ & 0.141 & Not Significant \\
\hline
\end{tabular}

Table 5: Interaction between LOG Return of the Mutual Funds before January 2008 and from January 2008 (using equality of means ' $t$ ' test)

\begin{tabular}{|l|l|l|l|l|}
\hline & $\mathbf{2 0 0 8}$ (using equality of means 't' test) & S Value \\
\hline DSPBR Eq & Mean \pm SD (PRE) & Mean \pm SD (POST) & P Value & SIG \\
\hline DSPBR Top 100 Eq Reg G & $0.03 \pm 0.07$ & $-0.01 \pm 0.07$ & 0.210 & S \\
\hline DWS Investment Oppor & $0.05 \pm 0.05$ & $0 \pm 0.06$ & 0.051 & NS \\
\hline HDFC Growth & $0.05 \pm 0.06$ & $-0.01 \pm 0.06$ & 0.030 & NS \\
\hline ICICI Pru Infra & $0.05 \pm 0.05$ & $0 \pm 0.07$ & 0.103 & S \\
\hline Kotak Oppor & $0.06 \pm 0.06$ & $-0.01 \pm 0.06$ & 0.016 & NS \\
\hline Reliance Growth & $0.05 \pm 0.06$ & $0 \pm 0.07$ & 0.046 & S \\
\hline Reliance Regular Savings Eq & $0.05 \pm 0.07$ & $0 \pm 0.07$ & 0.097 & S \\
\hline SBI (Magnum) Contra & $0.05 \pm 0.05$ & $0.01 \pm 0.09$ & 0.090 & NS \\
\hline Sundaram Select Midcap Reg G & $0.04 \pm 0.06$ & $0 \pm 0.07$ & 0.164 & NS \\
\hline Tata Eq PE & $0.05 \pm 0.05$ & $0 \pm 0.07$ & 0.126 & NS \\
\hline UTI Div Yld & $0.04 \pm 0.05$ & $0 \pm 0.06$ & 0.062 & NS \\
\hline
\end{tabular}

\section{1) Analysis 1:}

\section{Results And Conclusion}

The coefficient of variation was comparatively less for the company scrips than that of the Mutual Fund Schemes. In some cases the Mutual Fund Schemes have a massive variability in their return as compared to the Sensex. However few of the sample funds have shown less variability like UTI Dividend Yield (Public Sector Mutual Fund Scheme) thereby becoming the more reliable and stable series as compared to the other 
Mutual Fund schemes analyzed in this study. Thus one can say that in the given study period the variability in the return of the Mutual Fund Schemes are between moderate to high and thus these Mutual Fund Schemes may not be as stable as they seem to be. Also there is moderate to high variability in the return of the Company Scrips. However it is not as high as some of the studied mutual Fund Schemes. The investors should weigh their options carefully before deciding to invest in a Mutual Fund Scheme or a Company Scheme directly as both the investment styles have variability in return generated.

\section{2) Analysis 2:}

The RSQ was high indicating diversification to minimize Beta, the Alpha was negative in some funds (DWS Investment Opportunities Reg G, ICICI Pru Infrastructure, Kotak Opportunities G and SBI (Magnum) Contra G). This indicated that the fund managers were not so efficient in selecting stocks for all the funds. This was probably because as the study period is during the global meltdown, it was difficult for the managers to predict the performance of a stock due to extreme fluctuation in the financial markets.

\section{3) Analysis 3:}

In most of the funds the Sharpe Ratio was positive throughout the study period, indicating that their return was more than the Risk Free Return. Thus the studied Mutual Fund Schemes have generated a return more than the Risk Free Rate of Return. In this context it can be beneficial to invest in these funds.

\section{4) Analysis 4:}

7.4.1) For the sample Mutual Fund Schemes the annualized return before January 2008 is same as annualized return after January 2008. Thus in this case there is a statistically significant variation in the means of the two samples of time period chosen.

7.4.2) For the sample Mutual Fund Schemes the annualized return before January 2008 is same as annualized return after January 2008. Thus in this case there is a statistically significant variation in the means of the two samples of time period chosen.

Though the return generated by the Mutual Fund Schemes studied here fluctuated a lot during the Global Economic Meltdown, when taken as an overall pattern in two distinct sample sets, the pre and post January 2008 return of these schemes show no significant variation. As the 'pre January 2008' set is being considered to be a picture of the pre- global melt down financial market and the 'post January 2008' set, of the global melt down financial market, one can say that there has not been a huge fluctuation in the annualized return generated by the 12 Mutual Fund Schemes studied here in the two sample periods. Thus to a certain extent these Mutual Fund Schemes have been able to absorb the severe fluctuations in the financial market during the global economic meltdown.

Through this four part analysis one can conclude that in the given study period which is December 2008 to December 2012

- There is a statistically significant variation in the return generated by the Mutual Fund Schemes as compared to the 10 chosen Company scrips and the Sensex.

- The Coefficient of Variation of the Public Sector Mutual Fund Schemes is comparatively less than the Private Sector Mutual Fund Schemes, the 10 chosen company scrips and the Sensex.

- The Coefficient of Variation of the Private Sector Mutual Fund Schemes is moderate (some of them have a coefficient less than that of Sensex and two of them have a slightly higher coefficient than the Sensex). However the variability is more or less similar to that of the Sensex and the Company Scrips.

- The Coefficient of Variation of the Foreign Sector Mutual Fund Schemes is comparatively much higher than that of the Sensex and most of the chosen 10 Company scrip.

- The fund managers were not so efficient in selecting stocks for all the funds.

- In most of the funds the Sharpe Ratio was positive throughout the study period, indicating that their return was more than the Risk Free Return.

- The pre and post January 2008 return of these schemes show no significant variation.

So it cannot be said that investing in Mutual Fund Schemes is completely risk free and investors should weigh their options carefully before deciding to invest in a Mutual Fund Scheme or a Company Scheme directly as both the investment styles have variability in return generated. Fund managers should be careful during stock selection. To a certain extent these Mutual Fund Schemes have been able to absorb the severe fluctuations in the financial market during the global economic meltdown.

\section{Scope Of Further Research}

Due to time and few inherent constraints, all aspects of the mutual funds could not be looked into exhaustively. The following areas could be considered as an extension of the present study. 
1. A study can be undertaken to understand the impact of capital market scams on mutual fund investments.

2. The sample of mutual fund schemes \& companies can be increased.

3. An extension of the time period beyond 2012 can be done to further analyse the effect of the aftermath of the global financial crisis.

4. An analysis of Fund managers' strategy and an impact of change in fund manager can be done.

5. A study can be done on the similar analysis on debt funds and then comparing them with equity funds.

\section{References}

[1]. Treynor, How to Rate Management of Investment Funds, Harvard Business Review, 43 (1), January-February, 1965, 63-75.

[2]. Sharpe, Mutual Fund Performance, Journal of Business, 39, 1966, 119-138.

[3]. Jensen, The Performance of Mutual Funds in the Period 1945-1964, Journal of Finance, 23(2), 1968, 389-416.

[4]. Fama, Components of Investment Performance, Journal of Finance, 27, 1972, 551-567.

[5]. Shashikant, Accounting Policy and Practices of Mutual Funds: The Need for Standardization, Prajan, 24 (2), $1993,91-102$.

[6]. Narasimhan and Vijayalakshmi, Performance Analysis of Mutual Funds in India, Finance India, 15 (1), March, 2001, 155-174.

[7]. Badrinath, Contra Fund in India: A Quick Look, Portfolio Organizer, January, 2008, 31-34.

[8]. Swaminathan, Performance of Mutual Funds in India: a Comparative Study of Public and Private Sector Mutual Funds (New Delhi, Gyan Publishing House, 2011).

[9]. Shitole and Thyagarajan, Performance Evaluation of Mutual Funds in India (New Delhi, Adhyayan Publishers and Distributors, 2012). 